\title{
PENERAPAN METODE TARGET COSTING DALAM PERENCANAAN BIAYA PRODUKSI UNTUK OPTIMALISASI LABA PADA UMKM DENDENG SAPI ACEH DI BANDA ACEH
}

\author{
Cut Affiqah*1, Raida Fuadi ${ }^{* 2}$ \\ 1,2Program Studi Akuntansi Fakultas Ekonomi dan Bisnis Universitas Syiah Kuala \\ e-mail: fhieqahh234@gmail.com ${ }^{* 1}$, raidafuadi@ yahoo.com ${ }^{* 2}$
}

\begin{abstract}
The purpose of this research was to apply the target costing to the Aceh Cow Beef Jerky Community so that it addressed the difficulties of Aceh cow beef jerky producers in managing production costs and also helped increase the profits that the company could obtain. The type of research used is descriptive comparative research in the form of empirical studies with quantitative approaches. The population in this research were all the Aceh Cow Beef Jerky Community in Banda Aceh with research samples namely Rencong Aceh, Bungong Jaroe, and Gunung Seulawah. The sampling method used is non-probability sampling with a purposive sampling technique. The data sources used are primary data and secondary data. Data collection techniques used were interviews, observation, and documentation. In analyzing the data used target costing and value engineering calculations. Then compare the results of the profit target before and after the use of the target costing method. The results of this study indicate that after applying the target costing method, an increase in profit from the specified profit target is Bungong Jaroe of $2.44 \%$ and Rencong Aceh of $0.57 \%$.
\end{abstract}

Keywords: Target costing method, production cost, and optimize profits.

\section{Pendahuluan}

Kemajuan dalam dunia bisnis di Indonesia dari era ke era mengalami dampak positif. Kejadian ini dibuktikan dengan maraknya industri di Indonesia, mulai dari industri berskala kecil sampai industri berskala besar. Selain itu, banyak produk-produk baru yang bermunculan dengan keunggulannya masingmasing. Keunggulan ini merupakan strategi tetap yang dibangun oleh setiap perusahaan guna menghadapi persaingan yang semakin ketat. Pastinya semua perusahaan ingin memenangkan persaingan dan bertahan lama dalam dunia bisnis. Tanpa memenangkan persaingan, perusahaan tidak akan berkembang dan secara otomatis dapat membuat perusahaan berada dalam kebangkrutan. Hal inilah yang mendorong manajemen perusahaan untuk selalu bijaksana dalam menentukan suatu tindakan dengan memilih keputusan alternatif agar tercapainya tujuan perusahaan. Tujuan perusahaan paling utama adalah optimalisasi laba.

Dalam optimalisasi laba terdapat prinsip-prinsip ekonomi yang menjadi pegangan kuat bagi perusahaan dalam menjalankan bisnisnya. Prinsip ekonomi tersebut yaitu memperoleh laba semaksimal mungkin dan meminimalisasikan biaya seminimal mungkin tanpa mengurangi kualitas yang terdapat dalam suatu produk tersebut.

Berbicara mengenai kualitas produk, tentu hal ini menjadi prioritas utama bagi pelaku usaha dalam menghasilkan produk-produk bisnisnya. Namun, permasalahan yang terjadi saat ini yaitu apabila perusahaan hanya mengedepankan kualitas produk tanpa memikirkan persaingan harga jual maka dikhawatirkan perusahaan tersebut akan kalah dalam persaingan harga jual yang berakibat tidak tercapainya optimalisasi laba yang diinginkan.

Mengatasi situasi ini, manajemen dalam suatu perusahaan harus memiliki perencanaanperencanaan yang baik. Salah satu perencanaan yang akan digunakan dalam penelitian ini untuk mencapai optimalisasi laba yaitu perencanaan biaya produksi. Perencanaan biaya produksi termasuk dalam perencanaan strategis karena memiliki tujuan jangka panjang dalam pelaksanaannya.

Usaha mikro, kecil, dan menengah atau disingkat menjadi UMKM merupakan salah satu 
bagian terpenting dari perekonomian negara maupun daerah, khususnya di wilayah Indonesia karena peranannya yang telah membantu negara dan pemerintah dalam menciptakan lapangan kerja baru bagi masyarakat, meratakan tingkat perekonomian rakyat kecil dan meningkatkan pemasukan devisa bagi negara. Namun, kinerja nyata yang dihadapi oleh sebagian besar UMKM di Indonesia masih memprihatinkan. Hal yang paling mencolok diantaranya masih rendahnya kualitas produk, masih rendahnya tingkat produktivitas dan nilai tambah produk di perusahaan. Tidak hanya itu, dendeng sapi Aceh yang di pasar kan pun harga jual nya bervariasi. Misalnya, dendeng sapi Aceh di UMKM A harga jualnya Rp210.000, sedangkan di UMKM B memiliki harga jual lebih besar sebanyak Rp240.000. Perbedaan harga jual bervariasi di masing-masing UMKM Dendeng Sapi Aceh ini juga yang membuat peneliti tertarik mengkaji ulang mengenai perencanaan biaya produksi di setiap UMKM Dendeng Sapi Aceh dalam menentukan harga jual produk dendeng.

Pada penelitian ini, peneliti akan memperkenalkan suatu metode yang dapat membantu para UMKM Dendeng Sapi Aceh dalam menentukan harga jual produk dengan laba yang diinginkan dan tentunya kualitas produk akan tetap terjaga baik. Metode yang dimaksud disebut dengan nama metode "target costing". Peneliti akan mencoba untuk mengurangi biaya produk pada tahap desain dengan penggunaan target costing. Dimana pada tahap desain, perusahaan dapat menentukan bahan-bahan apa yang diperlukan dalam memproduksi barangnya dan bahan alternatif apa yang dapat menjadi pengganti dengan harga murah, kualitas baik dan sesuai kriteria agar kualitas produk tetap terjaga. Disinilah perusahaan dapat menyiasati serta menurunkan biaya pada saat terjadi proses perencanaan produksi.

Dari hasil penelitian sebelumnya, terdapat beberapa perbedaan hasil dan kesimpulan. Penelitian oleh Longdong (2016), menyimpulkan bahwa penerapan pendekatan target costing dengan menggunakan pengendalian biaya berupa rekayasa nilai mampu menekan biaya pada saat proses perencanaan produksi. Penelitian oleh Caroline dan Heince (2016), menyimpulkan bahwa metode target costing belum tepat diterapkan dalam perhitungan biaya produksi di UD (Usaha Dagang) Bogor Bakery karena target biaya yang ditentukan perusahaan sangat tinggi dari biaya produksi yang sebenarnya. Penelitian oleh Rachmatulloh, Epi \& Rini (2015), menyimpulkan bahwa penerapan target costing untuk meningkatkan laba CV (Comanditaire Venootschap) Onderhoud Company menunjukkan kriteria memadai.

Penelitian ini bertujuan untuk menerapkan target costing pada UMKM Dendeng Sapi Aceh sehingga menjawab kesulitan dari produsen dendeng sapi Aceh dalam mengelola biaya produksi dan juga membantu meningkatkan laba yang dapat diperoleh perusahaan. Hal inilah yang mendorong peneliti tertarik untuk membuat penelitian dengan judul "Penerapan Metode Target Costing dalam Perencanaan Biaya Produksi untuk Optimalisasi Laba pada UMKM Dendeng Sapi Aceh Di Banda Aceh".

\section{Kerangka Teoritis Akuntansi Manajemen}

Samryn (2013:4) menyatakan bahwa, akuntansi manajemen merupakan bidang akuntansi yang berfokus pada penyediaan, termasuk pengembangan dan penafsiran informasi akuntansi bagi para manajer untuk digunakan sebagai bahan perencanaan, pengendalian operasi dan dalam pengambilan keputusan.

\section{Perencanaan}

Raiborn \& Michael (2014:406) mengemukakan bahwa, perencanaan merupakan peletakan dasar dari manajemen yang efektif, dan dalam situasi yang kompleks, perencanaan yang berhasil membutuhkan prediksi dari para manajer, dengan presisi yang beralasan, variabel kunci yang memengaruhi kinerja perusahaan. Perencanaan yang baik akan menghasilkan output baik juga, sedangkan perencanaan yang buruk akan menghasilkan output buruk bahkan merugikan pihak lain. Perencanaan dapat bersifat jangka panjang pelaksanaan dan keefektifan nya juga dapat pula bersifat jangka pendek pelaksanaannya.

\section{Biaya Produksi}

Biaya produksi adalah biaya yang dibutuhkan oleh perusahaan untuk mendapatkan bahan baku (mentah) dari pemasok dan membuatnya menjadi produk selesai yang siap dijual (Sodikin, 2015 dalam Longdong, 2016:1411). Biaya terdiri atas beberapa klasifikasi yaitu biaya berdasarkan elemen biaya 
produksi, biaya berdasarkan hubungannya dengan objek biaya, dan biaya berdasarkan reaksinya terhadap perubahan dalam aktivitas.

\section{Rantai Nilai}

Rantai nilai (value chain) merupakan sebuah perangkat fungsi penambahan nilai atau proses yang mengubah input menjadi sebuah produk atau jasa untuk para pelanggan perusahaan (Raiborn \& Michael, 2014:14). Adapun beberapa komponen rantai nilai yaitu riset dan pengembangan, desain, persediaan, produksi, pemasaran, distribusi, dan layanan pelanggan. Komponen rantai nilai berperan dalam penambahan nilai pada produk atau jasa bagi pelanggan perusahaan. Dalam rantai nilai terdapat suatu metode yang yang digunakan perusahaan untuk optimalisasi laba yang disebut dengan metode "target costing".

\section{Target Costing}

Wijaksono (2013) dalam Hafid (2017:24) menyatakan bahwa, target costing adalah suatu sistem dimana penentuan harga pokok produksi sesuai dengan yang diinginkan (target) sebagai dasar penetapan harga jual produk yang akan memperoleh laba yang diinginkan atau penentuan harga pokok sesuai dengan harga jual yang pelanggan rela membayarnya. Biaya target untuk membuat sebuah produk dihitung dengan cara yaitu:

Target Biaya $=$ Harga jual yang ditargetkan Keuntungan yang ditargetkan

Menurut Atkinson, et al (2012:11) ada beberapa tahapan langkah dan sistematika pemikiran untuk biaya produk pada perhitungan biaya berdasarkan target, yaitu riset pasar, desain dan perekayasaan secara serentak (concurrent design and engineering), perhitungan biaya berdasarkan harga (price-led costing), proses perekayasaan nilai (value engineering process), tim produksi lintas-fungsi, dan manajemen rantai penawaran (supply chain management).

\section{Laba}

Soemarso (2009) dalam Rachmatulloh, Epi \& Rini (2015:156) menyatakan bahwa, laba adalah selisih pendapatan atas biaya-biaya yang terjadi sehubungan dengan usaha untuk memperoleh pendapatan tersebut selama periode tertentu. Perencanaan laba yang cermat sebaiknya mengikuti perkembangan teknologi dan faktor-faktor sosial, ekonomi dan politik yang berpengaruh kuat dalam dunia usaha.

\section{Metode Penelitian \\ Desain Penelitian}

Desain penelitian yang digunakan dalam penelitian ini adalah penelitian komparatif deskriptif berupa studi empiris dengan pendekatan kuantitatif. . Komparatif dapat membandingkan perbedaan waktu karena suatu perlakuan dan perbedaan subjek (Wijaya, 2013:6). Penelitian komparatif bersifat ex post facto. Desain ex post facto merupakan desain penelitian empiris yang sistematis dan peneliti tidak dapat mengatur dan memanipulasi variabel bebas secara langsung (Sumarni \& Salamah, 2006:52). Sarwono (2013:2) menyatakan bahwa, empirisme merupakan suatu pandangan yang mengatakan bahwa kita hanya dapat sampai pada pemahaman terhadap kejadiankejadian yang secara langsung dapat kita observasi dengan menggunakan indra kita.

\section{Populasi dan Sampel Penelitian}

Populasi dalam penelitian ini adalah seluruh UMKM Dendeng Sapi Aceh di Banda Aceh yang tercatat pada Dinas Koperasi dan Usaha Mikro Kecil Menengah Kota Banda Aceh. Menurut data yang diperoleh, ada 15 UMKM Dendeng Sapi Aceh yang terdaftar. Setelah penulis melakukan survei, dipilih lah 3 UMKM Dendeng Sapi sebagai sampel yaitu Gunung Seulawah, Bungong Jaroe, dan Rencong Aceh. Pemilihan sampel dalam penelitian ini berdasarkan purposive sampling dengan kriteria-kriteria sebagai berikut:

1) UMKM Dendeng Sapi Aceh yang memiliki kriteria kecil.

2) Memiliki nama merek usaha dendeng sapi Aceh (contoh: Gunung Seulawa

3) UMKM Dendeng Sapi Aceh yang masih aktif berproduksi.

4) Memproduksi dendeng sapi Aceh secara rutin.

\section{Sumber dan Teknik Pengumpulan Data}

Sumber data yang digunakan adalah data primer dan data sekunder. Sumber data primer diperoleh secara langsung dengan mewawancarai pemilik UMKM dendeng sapi Aceh guna mengumpulkan datadata yang diinginkan. Sedangkan data sekunder adalah 
data yang dikumpulkan oleh peneliti dari studi pustaka dan data yang berupa data yang sudah jadi, seperti keterangan tertulis, resep pembuatan produk dendeng sapi Aceh, dan data list perlengkapan dan peralatan. Data-data yang sudah didapatkan kemudian akan diolah oleh peneliti. Pada penelitian ini, peneliti menggunakan horizon waktu dengan data cross sectional. Data cross sectional yaitu informasi yang diperoleh dari suatu waktu atau saat tertentu (Wijaya, 2013:20).

Teknik pengumpulan data yang digunakan adalah wawancara, observasi, dan dokumentasi. Dalam pengumpulan data, peneliti mewawancarai pemilik UMKM Dendeng Sapi Aceh untuk mendapatkan data secara langsung dari sumber. Kemudian peneliti juga melakukan observasi guna menghasilkan deskripsi yang mendalam tentang organisasi atau peristiwa, untuk memperoleh informasi yang tidak dapat diakses dan melakukan penelitian ketika metode lain tidak berjalan. Terakhir, peneliti juga mengumpulkan dokumentasi. Dokumentasi adalah cara pengumpulan data dengan menggunakan arsip atau dokumen-dokumen yang bersifat tulisan dari perusahaan yang bersangkutan.

\section{Instrumen Penelitian}

Instrumen yang digunakan dalam penelitian ini adalah kuesioner sebagai pedoman wawancara yang ditujukan kepada pemilik UMKM Dendeng Sapi Aceh.

\section{Metode Analisis Data}

Langkah-langkah yang akan dilakukan untuk menganalisis data penelitian ini yaitu:

1) Menyusun daftar pertanyaan dan melakukan wawancara untuk mendapatkan data dari pemilik UMKM Dendeng Sapi Aceh.

2) Mendatangi objek penelitian pada saat melakukan proses produksi untuk melakukan observasi dan mengambil data-data yang berhubungan dengan penelitian.

3) Melakukan uji keabsahan data dengan menggunakan triangulasi. Menurut Moleong (2004:178), Triangulasi adalah teknik pemeriksaan keabsahan data yang memanfaatkan sesuatu yang lain di luar data itu untuk keperluan pengecekan atau sebagai pembanding terhadap data itu. Teknik triangulasi yang paling banyak digunakan adalah pemeriksaan melalui sumber lainnya.

4) Melakukan perhitungan dan perincian biaya produksi yang terjadi pada proses produksi dendeng sapi sebagai pembanding awal.

5) Melakukan penerapan target costing pada UMKM Dendeng Sapi Aceh sebagai alternatif pembanding kedua.

6) Membandingkan antara biaya produksi yang terjadi dengan perhitungan alternatif.

7) Melakukan analisis dan review penggunaan target costing pada produsen dendeng sapi.

\section{Hasil Penelitian}

Pada penelitian ini, penulis membahas tentang penerapan metode target costing dalam perencanaan biaya produksi untuk optimalisasi laba. Dimana pada setiap UMKM Dendeng Sapi Aceh nanti akan diterapkan metode target costing dalam biaya produksi apabila biaya produksi masing-masing yang telah ditetapkan tidak memenuhi target laba. Sampel penelitian yang diambil pada penelitian ini adalah 3 (tiga) UMKM Dendeng Sapi Aceh yaitu Gunung Seulawah, Bungong Jaroe, dan Rencong Aceh.

\section{Gambaran Umum Perusahaan}

Dendeng Gunung Seulawah adalah produsen pertama dalam penjualan dendeng sapi kuliner khas Aceh sejak tahun 1977 yang beralamatkan Jalan Teuku Chik Ditiro No. 29-31 di Banda Aceh. Dendeng Bungong Jaroe merupakan usaha dagang dendeng milik pak Mahdi beralamatkan di Jalan Teuku Umar No. 149 Setui dan berdiri sejak tahun 2006. Sedangkan, Dendeng Rencong Aceh merupakan usaha dagang dendeng milik pak Said Husain yang berdiri sejak tahun 2000 dan beralokasi di Jalan Muhammad Jam, Lamseupeung.

\section{Proses Produksi Dendeng Sapi Aceh}

Pada dasarnya, proses produksi dendeng sapi Aceh di ketiga UMKM dendeng ini adalah sama namun mereka memiliki resep khas tersendiri untuk menarik minat pelanggannya. Proses produksi dendeng sapi Aceh dapat dibedakan menjadi beberapa tahap, yaitu pengadaan bahan baku, pembersihan, penyayatan, penggilingan bahan tambahan, 
pencampuran bahan tambahan dengan daging sayatan, pemeraman, penjemuran, dan pengemasan.

\section{Perhitungan Biaya Produksi Dendeng Sapi Aceh}

Biaya produksi dendeng sapi Aceh terdiri dari biaya bahan baku, biaya tenaga kerja, dan biaya overhead pabrik. Total biaya produksi perbulan pada Gunung Seulawah yaitu Rp447.841.567 dengan biaya bahan baku sebesar Rp424.400.000, biaya tenaga kerja sebesar Rp13.500.000, dan biaya overhead pabrik sebesar Rp9.941.567. Selanjutnya, total biaya produksi perbulan pada Bungong Jaroe yaitu Rp251.935.483 dengan biaya bahan baku sebesar Rp233.185.000, biaya tenaga kerja sebesar Rp9.100.000, dan biaya overhead pabrik sebesar Rp9.650.483. Terakhir, total biaya produksi perbulan pada Rencong Aceh yaitu Rp19.449.954 dengan biaya bahan baku sebesar Rp16.092.000, biaya tenaga kerja sebesar Rp2.700.000, dan biaya overhead pabrik sebesar Rp657.954.

\section{Perhitungan Biaya Produksi Alternatif Menggunakan Target Costing}

Dalam penelitian ini, Gunung Seulawah dijadikan sebagai patokan utama atau panutan yang dapat dicontoh oleh perusahaan dendeng lainnya karena Gunung Seulawah sebelumnya telah menerapkan target costing dan mampu menekan biaya produksi untuk optimalisasi laba. Adapun penerapan target costing dengan langkah-langkah sebagai berikut:

1) Perhitungan biaya berdasarkan harga (price-led costing) yaitu dengan menentukan target harga, target laba, dan menghitung target biaya

Harga jual produk masing-masing UMKM Dendeng Sapi Aceh yaitu Bungong Jaroe sebesar Rp220.000/kg, sedangkan Gunung Seulawah dan Rencong Aceh sebesar Rp240.000/kg. Selanjutnya, berdasarkan hasil wawancara, target laba yang diharapkan dari ketiga UMKM Dendeng Sapi Aceh tersebut adalah 25\% dari harga jual per unit produk. Setelah menentukan target harga dan target laba, langkah selanjutnya yaitu menghitung target biaya. Adapun rumus yang digunakan yaitu:

Target Biaya = Harga jual yang ditargetkan Keuntungan yang ditargetkan
Dari hasil penelitian, berikut target biaya produksi yang didapat yaitu Gunung Seulawah sebesar Rp450.000.000, Bungong Jaroe sebesar Rp247.500.000, dan Rencong Aceh sebesar Rp18.000.000.

2) Proses perekayasaan nilai (value engineering) Ada beberapa strategi yang dilakukan dalam proses perekayasaan nilai yaitu pengurangan biaya-biaya produksi yang tidak perlu dimasukkan ke dalam nilai harga jual, penambahan aset, penggantian desain, pemilihan bahan baku alternatif dengan harga yang lebih terjangkau dan berkualitas, dan lain sebagainya. Pada biaya bahan baku dendeng, peneliti melakukan pengurangan harga daging menjadi Rp90.000 (harga daging Gunung Seulawah) dan harga bawang putih menjadi Rp27.000 (harga bawang putih Gunung Seulawah) pada Bungong Jaroe dan Rencong Aceh. Selain itu, penulis juga melakukan perubahan pada kuantitas bahan baku gula dan bahan baku ketumbar dengan cara mengurangi kuantitas gula sebesar $10 \%$ dan kuantitas ketumbar sebesar 10\% pada Bungong Jaroe dan Rencong Aceh. Sehingga hasil yang didapat yaitu kuantitas gula Bungong Jaroe sebesar $180 \mathrm{~kg}$ dan Rencong Aceh sebesar $126 \mathrm{~kg}$ juga kuantitas ketumbar Bungong Jaroe sebesar $180 \mathrm{~kg}$ dan Rencong Aceh sebesar $19 \mathrm{~kg}$. Peneliti tidak melakukan perubahan terhadap tenaga kerja dan overhead pabrik dikarenakan biaya yang ditetapkan sudah sesuai dengan kebutuhan perusahaan. Setelah melakukan proses perekayasaan nilai, maka didapatlah total biaya produksi alternatif menggunakan target costing yaitu Bungong Jaroe sebesar Rp239.455.483 dengan biaya bahan baku sebesar Rp220.705.000, biaya tenaga kerja sebesar Rp9.100.000, dan biaya overhead pabrik sebesar Rp9.650.483 dan Rencong Aceh sebesar Rp17.862.954 dengan biaya bahan baku sebesar Rp14.505.000, biaya tenaga kerja sebesar Rp2.700.000, dan biaya overhead pabrik sebesar Rp657.954.

\section{Perhitungan Laba pada UMKM Dendeng Sapi Aceh Di Banda Aceh Sebelum dan Sesudah Menerapkan Metode Target Costing}

Rumus laba untuk perusahaan manufaktur yaitu penjualan dikurangi dengan harga pokok penjualan. 
Penjualan Bungong Jaroe selama sebulan yaitu sebesar Rp330.000.000 (Rp220.000 x 1500 unit) dan penjualan Rencong Aceh selama sebulan yaitu sebesar Rp24.000.000 (Rp240.000 x 100 unit). Bungong Jaroe dan Rencong Aceh tidak memiliki persediaan barang dalam proses, sehingga biaya produksi dijadikan harga pokok produksi. Mereka juga tidak memiliki persediaan barang jadi, sehingga harga pokok produksi dijadikan harga pokok penjualan. Dari hasil perhitungan maka didapatlah perbandingan laba sebelum dan sesudah menerapkan metode target costing yaitu laba sebelum menerapkan target costing pada Bungong Jaroe sebesar Rp78.064.517 (Rp330.000.000 - Rp251.935.483) dan laba sesudah menerapkan target costing pada Bungong Jaroe sebesar Rp90.544.517 (Rp330.000.000 Rp239.455.483), sedangkan laba sebelum menerapkan target costing pada Rencong Aceh sebesar Rp4.550.046 (Rp24.000.000 - Rp19.449.954) dan laba sesudah menerapkan target costing pada Rencong Aceh sebesar Rp6.137.046 (Rp24.000.000 Rp17.862.954).

\section{Pembahasan}

\section{Analisis dan Review}

Berdasarkan hasil penelitian, Gunung Seulawah telah mencapai target laba sehingga tidak diperlukan adanya perhitungan biaya produksi alternatif. Sedangkan Bungong Jaroe dan Rencong Aceh harus menghitung biaya produksi alternatif dengan melakukan perekayasaan nilai untuk mencapai target laba guna optimalisasi laba. Selisih persentase antara target laba Bungong Jaroe dengan laba sesudah menerapkan metode target costing adalah 2,44\%, artinya ada kenaikan dari target laba yang ditentukan untuk mencapai optimalisasi laba. Begitu juga dengan selisih antara target laba Rencong Aceh dan laba sesudah menerapkan metode target costing sebesar $0,57 \%$ mengalami kenaikan dari target laba.

Pada rekayasa nilai, ada beberapa langkahlangkah yang diambil oleh peneliti sehingga terjadi perubahan dalam biaya produksi yaitu pengurangan kuantitas bahan baku, dan harga beli bahan baku. Alasan peneliti mengurangi kuantitas bahan baku seperti bahan baku gula dan bahan baku ketumbar adalah karena peneliti berpendapat bahwa kuantitas gula dan ketumbar tersebut terlalu banyak. Mengurangi kuantitas bahan baku mungkin akan sedikit mengurangi kualitas, namun peneliti mencoba untuk mengurangi nya sewajar mungkin dan realistis. Selanjutnya peneliti juga mengurangi harga beli bahan baku pada Bungong Jaroe dan Rencong Aceh disebabkan harga beli yang terlalu tinggi. Untuk mengurangi nya peneliti mengacu pada harga beli Gunung Seulawah yang lebih murah.

\section{Rekomendasi}

Data-data diatas menunjukkan keberhasilan penerapan target costing dalam mengurangi biaya produksi pada produsen dendeng sapi Aceh. Dengan metode ini UMKM Dendeng Sapi Aceh dapat mengelola biaya produksinya dengan cermat dan baik. Target laba yang diinginkan oleh UMKM Dendeng Sapi Aceh sebesar 25\% dari harga jual tercapai dengan menggunakan target costing. Oleh karena itu, penulis merekomendasikan penerapan metode ini pada UMKM Dendeng Sapi Aceh agar dapat digunakan dalam mengelola biaya produksinya.

\section{Kesimpulan dan Saran}

Berdasarkan hasil analisis yang dilakukan, diperoleh kesimpulan sebagai berikut:

1) Berdasarkan hasil wawancara mengenai penerapan metode target costing yang dilakukan pada UMKM Dendeng Sapi Aceh di Banda Aceh menunjukkan bahwa hanya UMKM Gunung Seulawah yang sudah menerapkan metode target costing. Adapun langkah-langkah dalam penerapan metode target costing yaitu perhitungan biaya berdasarkan harga (price-led costing) dengan cara menentukan target harga, target laba, dan menghitung target biaya, kemudian proses perekayasaan nilai (value engineering) untuk mengurangi biaya produksi.

2) Menurut hasil penelitian, masing-masing biaya produksi yang dihasilkan yaitu Gunung Seulawah sebesar Rp447.841.567, Bungong Jaroe sebesar Rp251.935.483, dan Rencong Aceh sebesar Rp19.449.954. Perencanaan biaya produksi terdiri atas biaya bahan baku, biaya tenaga kerja, dan biaya overhead pabrik.

3) Berdasarkan hasil penelitian mengenai optimalisasi laba yang dilakukan pada UMKM Dendeng Sapi Aceh di Banda Aceh menunjukkan bahwa hanya Gunung Seulawah 
yang dapat mengoptimalisasi laba dengan baik. Terbukti dari hasil penelitian yang mengatakan bahwa Gunung Seulawah dapat mencapai laba lebih dari $25 \%$ dibandingkan dengan UMKM lainnya.

4) Berdasarkan hasil penelitian mengenai perbandingan laba yang dilakukan pada UMKM Dendeng Sapi Aceh di Banda Aceh sebelum dan sesudah menerapkan metode target costing menunjukkan bahwa laba yang dihasilkan mengalami peningkatan.

5) Berdasarkan hasil penelitian menunjukkan bahwa dengan adanya penerapan metode target costing maka UMKM Dendeng Sapi Aceh dapat mengoptimalisasi laba. Hal ini terbukti dari adanya setelah menerapkan metode target costing terjadi kenaikan laba dari target laba yang ditentukan.

Beberapa keterbatasan yang terdapat dalam penelitian ini. yaitu:

1) Terdapat unsur subjektifitas peneliti dalam proses penerapan metode target costing ini. Seperti mencari tindakan atau solusi dalam maksud menekan biaya produksi yang terjadi.

2) Kemungkinan terdapat solusi yang lebih baik lagi dalam menanggapi bagaimana menekan biaya produksi. Tetapi karena keterbatasan waktu yang singkat dalam melakukan penelitian ini, penulis berharap inilah yang terbaik yang dapat penulis berikan.

3) Data awal yang didapat dari hasil wawancara ini, mungkin masih kurang akurat bagi sebagian pembaca, namun penulis juga berusaha mencari data harga pasar untuk mendukung data awal yang didapat agar lebih akurat.

Berdasarkan penelitian yang telah dilakukan, saran yang dapat diberikan adalah sebagai berikut:

1) Pada penelitian selanjutnya diharapkan dapat menggunakan solusi yang lebih baik lagi daripada yang telah penulis berikan dalam penelitian ini. Seiring berjalannya waktu, kemungkinan terdapat solusi yang lebih baik lagi dan tepat diterapkan di masa yang akan datang.

2) Pada penelitian selanjutnya diharapkan peneliti mempersiapkan cukup waktu agar hasil penelitian yang didapatkan dapat lebih mendalam dan mendapatkan solusi yang lebih baik.

\section{Daftar Pustaka}

Anugerah, Eza Gusti. 2015. Penerapan Target Costing dalam Pengelolaan Biaya Produksi Untuk Peningkatan Laba Perusahaan (Studi Kasus pada Produsen Tape Sumber Madu). Skripsi. Jember: Universitas Jember.

Apriyanti, Erni. 2014. Penerapan Metode Target Costing dalam Perhitungan Harga Pokok Produksi. Jurnal Ilmu dan Riset Akuntansi, 3(4): 1-17.

Atkinson, Anthony A, et al. 2012. Management Accounting, Jilid 2, Edisi Kelima. Terjemahan Nayla M. Tazkiyah. Jakarta: Indeks.

Blocher, Edward., David E Stout, \& Gery Cokins. 2012. Manajemen Biaya Penekanan Strategis, Buku 2, Edisi 5. Jakarta: Salemba Empat.

Caroline, Tertius Clara \& Heince R.N. Wokas. 2016. Analisis Penerapan Target Costing dan ActivityBased Costing sebagai Alat Bantu Manajemen dalam Pengendalian Biaya Produksi pada UD. Bogor Bakery. Jurnal EMBA, 4(1): 593-603.

Hafid, Chaidir. 2017. Analisis Harga Pokok Produksi dan Penerapan Target Costing pada UD Wajuku Makassar. Skripsi. Makassar: Universitas Hasanuddin.

Khasanah, Roisatul., Kharis Raharjo, \& Hartono. 2017. Analisis Penerapan Metode Target Costing dalam Upaya Meningkatkan Efisiensi Biaya Produksi untuk Memaksimalkan Laba. Ekonomi-Akuntansi. 1-18.

Londong, Febriana Martina. 2016. Penerapan Target Costing dalam Perencanaan Biaya Produksi pada CV. Sinar Mandiri. Jurnal EMBA, 4(1): 1409-1418.

Madura, Jeff. 2009. Introduction to Business, Buku 1, Edisi 4. Terjemahan Ali Akbar Yulianto dan Krista. Jakarta: Salemba Empat.

Rachmatulloh, Citra Khaira., Epi Fitriah, \& Rini Lestari. 2015. Analisis Penerapan Target Costing untuk Meningkatkan Laba Perusahaan (Studi Kasus pada CV. Onderhoud Company Shoes and Leather). Prosiding Penelitian Sivitas Akademika Unisba (Sosial dan Humaniora).

Raiborn, Cecily A \& Michael R. Kinney. 2014. Cost Accounting: Foundations and Evolutions, Buku 
1, Edisi 7. Terjemahan Rahmat Hilman. Jakarta:

Salemba Empat.

Samryn, L.M. 2013. Akuntansi Manajemen: Informasi Biaya Untuk Mengendalikan Aktivitas Operasi dan Informasi, Edisi Revisi. Jakarta: Kencana.

Sarwono, Jonathan. 2013. Strategi Melakukan Riset. Yogyakarta: ANDI.

Sekaran, Uma \& Roger Bougie. 2013. Research Method for Business: A Skill-Building Approach, Sixth Edition. United Kingdom: John Wiley \& Sons Ltd.

Siregar, Baldric., dkk. 2016. Akuntansi Biaya, Edisi 2. Jakarta: Salemba Empat.

Wahyuni, Sari. 2012. Qualitative Research Method: Theory and Practice. Jakarta: Salemba Empat.

Wijaya, Tony. 2013. Metodologi Penelitian Ekonomi dan Bisnis: Teori dan Praktik, Edisi Pertama. Yogyakarta: Graha Ilmu.

Witjaksono, Armanto. 2013. Akuntansi Biaya, Edisi Revisi. Yogyakarta: Graha Ilmu. 